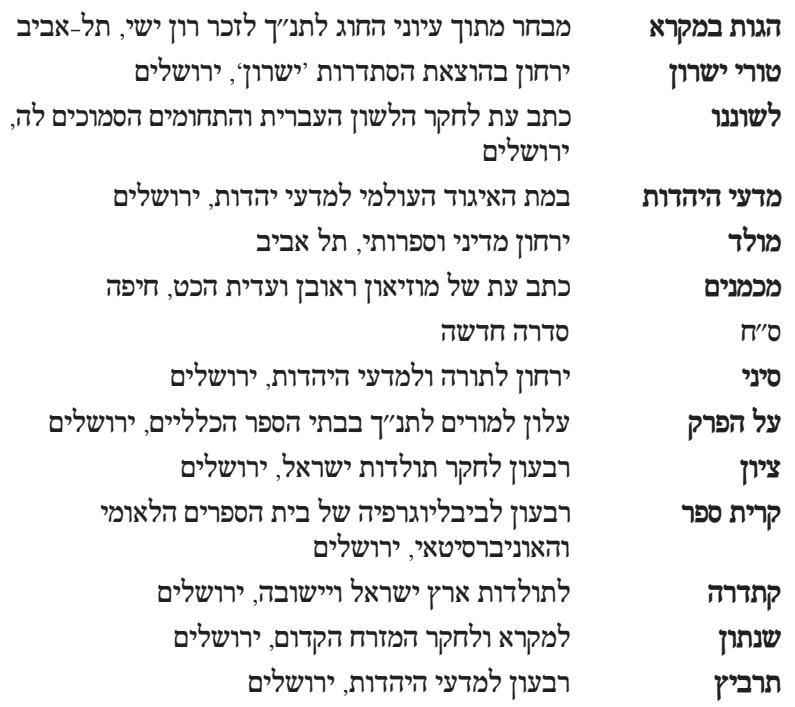

\title{
Subject Index to the Bibliography
}

Ancient Near Eastern documents: 6, 7, 39-40, 45, 50-52, 55-56, 60-61, 63-64, 73, 76-77, $79,86,89,94,96-97,105,120,127,129 ; * 13-* 14, * 22, * 25-* 26, * 28, * 35, * 37, * 40$, $* 47-* 48, * 56, * 65, * 67, * 71, * 74, * 76, * 85$

Biblical historiography: $4,24,29,72,96,103,123,141 ; * 16, * 34, * 53-* 54, * 75, * 98, * 110$, *115

Biblical theology: $23,30,51-52,58,75,88,101,106,138 ; * 39-* 40, * 49, * 79, * 82-* 83$, *89, $* 106, * 114, * 199, * 121$

Covenant: $\quad 6,33-35,39-40,69,108,113,124 ; * 4, * 14, * 18, * 20, * 25, * 36, * 55, * 60, * 74$, $* 95, * 100, * 102, * 106-* 107, * 117-* 118$

Cult and liturgy: $12 \mathrm{k}, 32,37,41,53,75,79,83,87,91-93,97,102,105,107,118-119,121$, $130 ; * 8, * 13, * 19, * 29, * 37, * 45, * 49, * 57, * 69, * 72, * 76-* 77, * 81, * 90, * 96-* 97, * 104$, $* 111, * 116, * 119-* 120$

Deuteronomy: $1-3,17-19,22,25,109,112,133 ; * 1, * 5, * 12-* 15, * 46, * 78, * 94, * 101, * 108$ Genesis: $\quad 8,27,47,73,99,131 ; * 28, * 33, * 48, * 59$

Idioms and expressions: $33,35,48,56,68,70,104,106,108,113,116,119,128-129,131$, $134,136-139 ; * 22, * 36, * 67, * 70, * 88, * 117-* 118$

Introduction to the Bible and history of interpretation: $5,28,46,57,59,67,71,82,95,98,110$, $126,132,142 ; * 3, * 9, * 23, * 30, * 32, * 51, * 82, * 121$

Israel, land of: $11,26,29,74,81,84-85,99,111,115,125 ; * 6, * 16, * 41, * 58-* 59, * 73, * 75$, $* 91$

Jerusalem as a political and religious capital: $90 ; * 44, * 80, * 86, * 101$

Justice, law, and legal institutions: $10,21,34,44,48-49,94 ; * 2, * 7, * 21, * 27, * 38, * 47, * 63$, $* 70, * 105, * 109, * 112$

New Testament: *29, *61, *84

Pentateuch and its law codes: $\quad 30,47,57,59,80,135,140,142 ; * 3, * 9, * 17, * 33, * 43$, *92-*93, $* 100, * 103, * 113$

Prophetic literature: $9,20,27,31,36,55,62,66,100 ; * 24, * 26, * 50, * 52$

Psalmodic literature: $38,50,76,77,120 ; * 35$

Qumran scrolls: $41,43,53-54,65,73,87-88,92-93,107,121-122 ; * 4, * 8, * 31, * 42, * 48$, $* 57, * 66, * 69, * 72, * 77, * 87-* 87 \mathrm{a}, * 90, * 99$

Ten Commandments and recitation of the Shema': $12,42,78 ; * 62, * 64, * 68$ 